\title{
The Impact of Embankment Construction on Floodplain Land Use in the Context of its Influence on the Environment: a Case Study of Selected Cities in Poland
}

\author{
Ewa Lechowska \\ Adam Mickiewicz University, Faculty of Geographical and Geological Sciences, \\ Department of Spatial Management, Poznań, Poland
}

Received: 25 May 2016

Accepted: 8 September 2016

\begin{abstract}
The main aim of this research was to analyse the impact of embankment construction on floodplain land use through a land use comparison of embanked and unembanked floodplains. Another purpose of was to assess the influence of studied floodplain land use on the environment. The analysis was conducted on the example of two cities along the Odra River in Poland: Oława and Brzeg, which significantly vary from each other in the level of river levee. The former one is embanked while the latter is not. The study has shown that in the cities studied there is a more beneficial method of floodplain spatial management in the embanked areas, both from the protection and functioning of the environment and for potential environmental contamination in the case of the perspective of flooding (in fact, these areas are less invested than the examined embanked areas), as well as the embankment being an important anthropogenic element that changes river valley land use. It is largely determined through hydrology (the change of water and soil conditions due to the creation of an embankment), but also by legal regulations in the range of spatial planning and economics in the floodplain areas.
\end{abstract}

Keywords: floodplains, land use, embankment, environment, Odra River

\section{Introduction}

River valleys are characterized by their high nature value. They constitute a dwelling place of numerous rare, dying out, or endangered species in Europe [1]. River valleys in Poland are distinguished by their unique biotopes - especially riparian forests and oak-hornbeam

*e-mail: ewaglo@amu.edu.pl forests [2]. In the majority of cases river valleys function as wildlife corridors [3].

Floodplains are also of high hydrological importance due to the high water retention capabilities of this ecosystem. Swamps (bogs and peat bogs) and forest complexes retain the highest retention value, while in floodplains the oxbow lakes and waterholes are significant in terms of so-called small water retention [cf. 4-5].

Because of the high soil fertility, flatness, availability of construction materials and near distance to river water, 
floodplains have always been very attractive for urban development and agricultural purposes. This has resulted in the construction of embankments that have cut off rivers from their floodplains. As a result, it is estimated that worldwide $50 \%$ of the wetland area is "lost," and in Europe this score is even higher [6]. This means that floodplains are the most threatened ecosystems among all ecosystem types [7].

Building floodbanks in river valleys has a negative impact on valley storage and the state of natural habitats. The embankment of the valley results in cutting its major parts off from access to river waters in full spate, therefore, as a consequence, there are fewer floods and the conditions of the habitat between the embankments [3, 5, 8-9]. River embanking causes an increase in height and speed of the flood wave in the inter-embankment zone [9-11].

Levees that are one of the technical activities commonly applied for flood protection brings the opposite effect. They raise the flood risk and transfer it to the lower course of a river [9-13]. Thus neither the strengthening nor heightening of existing dykes, as well as constructing new levees, doesn't solve the issue of flooding and does not provide complete flood protection (e.g., in the case residual or higher risk). There need to be other activities undertaken to avert flooding [9].

The water retention capabilities of a river valley also depend on both environmental conditions and, what is more important, human activity, including land use [9, 14]. The method of drainage basin use significantly impacts water quality, the river hydrological regime, and the state of the environment [15].

At present, the growth of urbanization of riversides which leads to the modification of hydrological conditions in the watershed, including the acceleration of the water cycle (increase runoff), can be observed [cf. 16-23]. Urban areas are characterized by a large number of impermeable or slightly permeable surfaces (e.g., buildings, roads, car parks, and pavement) that limit the rainwater soaking in the soil, resulting in the lowering levels of aquifers $[15,18$, $24]$. The high density of surface sewerage system in urban areas alters the paths of the rainwater outflow in relation to natural areas and increases the speed of water flow [15]. The usage of impermeable surfaces in the watershed is frequently considered a marker of urbanization level in surveys on the assessment of the influence of urbanized areas on hydrological conditions [25]. Ciupa's study [25] proved that the maximum outflow from the watershed in the city centre is three times higher than in forest areas and two times higher than in agricultural areas. The urbanization of floodplains also results in changes of hydraulic conditions of river valleys and the river hydrological regime [5, 19, 24, 26].

The main aim of this research was to analyse the impact of embankment construction on floodplain land use through a land use comparison of embanked and unembanked floodplains. Another purpose of was to assess the influence of studied floodplain land use on the environment.

\section{Study Area}

Research was conducted on the basis of the analysis of two cities: Brzeg and Oława, located along the Odra River (in its upper reaches) in Poland. These cities provide two opposing cases, considerably diverse in the degree of embankment of the river valley. Oława is embanked to a great degree from the side of the Odra, while Brzeg is practically unembanked. Due to a high level of embankment of the river valley of the Odra River, the surface of the strict floodplains (i.e., inter-embankment zone) in the river valley of the Odra corresponds with roughly $27 \%$ of the surface of natural floodplains [27]. Jermaczek, Misztal, and Wasiak [28] estimate that as a result of the development of the built-up areas in the valley of the Odra, three-quarters of the natural floodplains have been lost (i.e., especially unembanked floodplains).

The Odra is the border river between Poland and Germany and is one of the six biggest river systems in Europe [29]. The floodplains in the Odra drainage basin are used mainly for agriculture (above 70\%). Moreover, they are sparsely forested (about 18\%) [30]. The remains of historical forests, characteristic of especially boggy habitats, survive in the present inter-embankment zone and in the marshy areas cut-off from the river by embankments [27].

Brzeg and Olawa are located in the Wrocław Urstromtal, $15 \mathrm{~km}$ from each other, in the section from the Mała Panew outlet to the Kaczawa outlet. In this part of the urstromtal the width of the Odra valley ranges from 3 to $6 \mathrm{~km}$ and sometimes more. The Odra valley within the Wrocław Urstromtal is very diverse in terms of the degree of anthropogenic transformations and its uses [27].

The complex of the biocenoses forest that is considered the biggest and the most important in scale in Poland is located on the right bank of the Odra River, near Olawa, in the floodplains in the area of the researched cities. There are also large areas of marshy meadows [27]. Brzeg and Oława, in comparison with other cities on the Odra River, are notable due to riversides that are precious in nature. In both cities, more than $68 \%$ of the floodplains are protected by law as part of Natura 2000 in the form of Special Protection Areas (SPAs) (Figs 1-2).

In this study, floodplains are considered to be the areas at a direct and potential hazard of flooding corresponding with the flow of the floodwaters with the probability of flooding of $p=1 \%{ }^{1}$. In the case of embanked areas, the regions at direct hazard of flooding comprise the areas between the river channel and the embankments (the so-called inter-embankment zone), while the regions at potential hazard of flooding - the areas behind the embankments in the range of floodwaters $p=1 \%$ (the areas cut off from the river by embankments). Yet, in case of the unembanked areas the regions at direct hazard of flooding

\footnotetext{
${ }^{1}$ The extent of areas at a direct and potential risk of flooding was assigned in the Atlas of the Odra River Floodplains (Atlas terenów zalewowych rzeki Odry in Polish) by the Regional Water Managemnet Authority in Wroclaw (2003-06).
} 


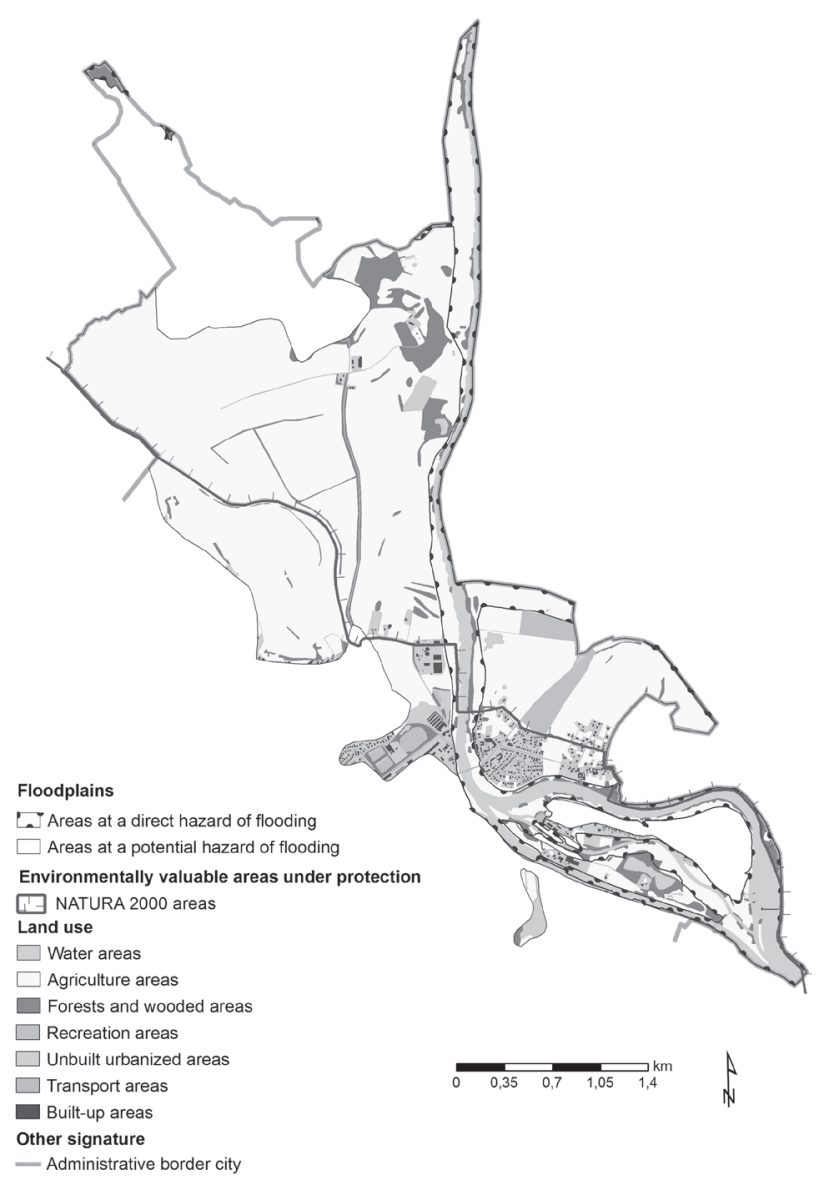

Fig. 1. Land use of floodplains in Oława in 2010.

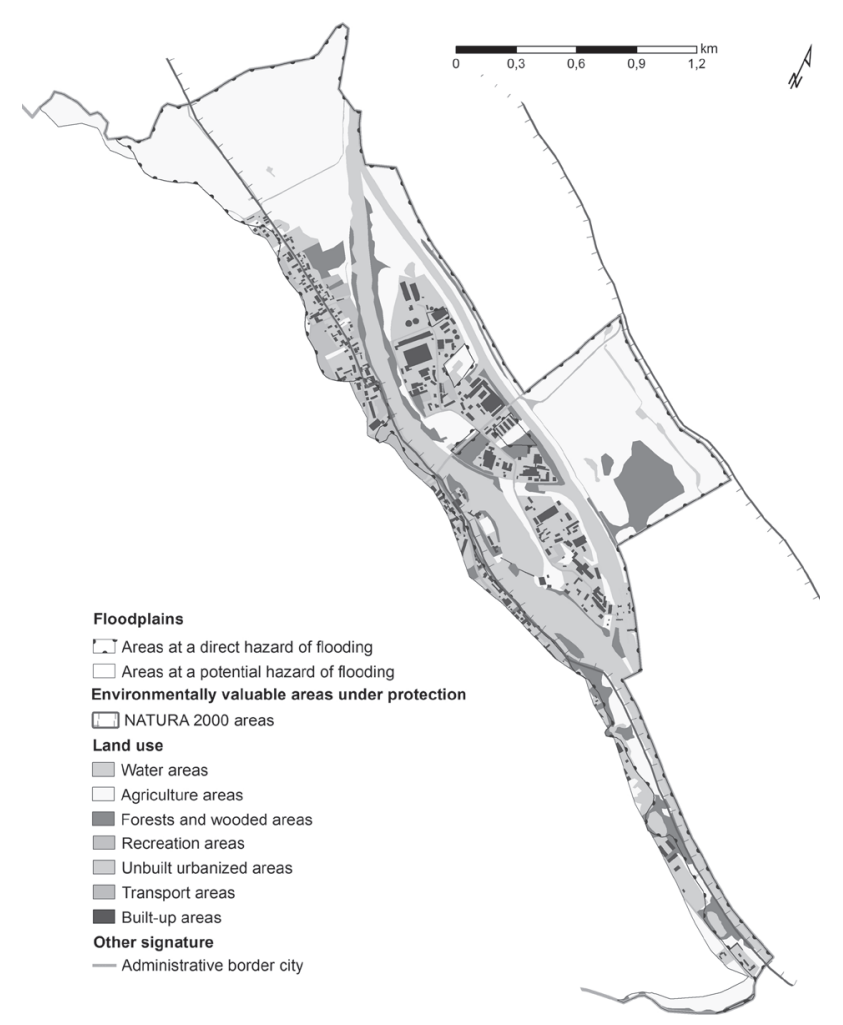

Fig. 2. Land use of floodplains in Brzeg in 2010. comprise an area with an ordinate standing for the water flow $\mathrm{p}=1 \%$ (including the sparse natural levees that are not a part of the constant system of flood protection) or to the level of the natural high bank, while the regions at potential hazard of flooding comprise the areas behind the mentioned local natural levees.

In both cities, around $26 \%$ (about a quarter) of their areas are at risk of being flooded. However, both in terms of the total surface of the flooding and the percentage of the area at hazard of flooding, Oława is more at risk of flooding than Brzeg, where more than $30 \%$ of the city's surface is at risk, with the majority of floodplains $(85 \%$ of their general surface) being protected by embankments situated fairly near the channel of the Odra. Brzeg, on the other hand, is not protected by embankments and the majority of floodplains constitute areas at direct hazard of flooding ( $88 \%$ of their general surface; Table 1$)$. The analyzed cities therefore differ in sizes of embanked areas and, consequently, in the specification of the areas at hazard of flooding.

\section{Methods}

In order to identify the forms of land cover and land use I used GIS tools to interpret ortophotomaps with the visual classification method for 2010. Visual interpretation of rasters requires the observer to outline manually all elements of land cover, adhering to the rule of the complementarity of polygons as well as topological correctness and coherence of the whole land cover. The efficiency and quality of work is greatly dependent on the knowledge and interpretation skills of the observer [31]. The minimum separate unit in the conducted photo interpretation of aerial images amounts to $10 \mathrm{~m}^{2}$.

The analysis of the structure of land cover and the developments of floodplains has been conducted on four analytical levels, distinguished on the basis of the classification of Baza Danych Obiektów Topograficznych (BDOT, Topographic Complexes Database) and the classification of Ewidencja Gruntów i Budynków (EGiB, Register of Lands and Buildings; Table 2). As a result, on the fourth and the most detailed level, the structure of the development of floodplains has been described through 24 forms of land development. From the perspective of the issues at hand (further on in the article), on the one hand special attention was paid to the analysis of such forms of development and land cover of:

1) Such urbanized areas as wheeled transport areas (roads), squares, built-up areas (especially industrial and storage buildings and technical infrastructure), and cemeteries

2) Biologically active areas such as water basins, forests and wooded areas, agricultural areas, recreation areas, and lawns.

It is assumed that the first above-mentioned group has a negative impact on the natural environment in the river valley due to the "sealing" of the area or the large potential source of environmental pollution in the case of flooding, 
Table 1. Sizes of floodplains in Brzeg and Oława.

\begin{tabular}{|c|c|c|c|c|c|c|}
\hline \multirow{2}{*}{ City } & \multicolumn{2}{|c|}{ Areas at direct risk of flooding } & \multicolumn{2}{|c|}{ Areas at potential risk of flooding } & \multicolumn{2}{c|}{ Areas at risk of flooding (in total) } \\
\cline { 2 - 7 } & ha & $\%$ & ha & $\%$ & ha & $\%$ \\
\hline Oława & 128.18 & 4.69 & 751.87 & 27.51 & 880.05 & 32.20 \\
\hline Brzeg & 253.33 & 17.52 & 33.72 & 2.33 & 287.05 & 19.85 \\
\hline
\end{tabular}

while the enumerated biologically active areas improve the retention capabilities of the river valley.

\section{Results and Discussion}

In the embanked floodplains in Oława the percentage of forested areas and wooded and bushy land, as well as agricultural land and land with surface water in the general surface of floodplains, is higher than in the unembanked floodplains in Brzeg (87.6\% and 69.8\% respectively). Similarly, the percentage of slightly permeable and impermeable areas (built-up areas, roads, and squares) is higher in Brzeg than in Oława (6.0\% and $1.6 \%$, respectively). In the analysis of floodplains, it is the regions at potential hazard of flooding that have a

Table 2. Classification of floodplain land use.

\begin{tabular}{|c|c|c|c|}
\hline First Level & Second Level & Third Level & Fourth Level \\
\hline \multirow{7}{*}{ Non-urbanized areas } & \multirow{2}{*}{ Water areas } & \multirow{2}{*}{ Water areas } & Flowing water areas \\
\hline & & & Stagnant water areas \\
\hline & \multirow{2}{*}{$\begin{array}{c}\text { Forests and } \\
\text { wooded areas }\end{array}$} & \multirow{2}{*}{ Forests and wooded areas } & Forests \\
\hline & & & Wooded areas \\
\hline & \multirow{3}{*}{ Agriculture areas } & \multirow{2}{*}{ Agricultural crops areas } & Meadows and pastures \\
\hline & & & Arable land \\
\hline & & Permanent crops areas & Orchards \\
\hline \multirow{17}{*}{ Urbanized areas } & \multirow{4}{*}{$\begin{array}{l}\text { Semi-invested } \\
\text { areas* }\end{array}$} & \multirow{4}{*}{ Recreation areas } & Cultivated green areas \\
\hline & & & Cemeteries \\
\hline & & & Allotments \\
\hline & & & Sport fields \\
\hline & \multirow{13}{*}{ Invested areas $* *$} & \multirow{2}{*}{ Unbuilt urbanized areas } & Lawn \\
\hline & & & Squares \\
\hline & & \multirow{2}{*}{ Transport areas } & Wheeled transport areas (roads) \\
\hline & & & Railway transport areas \\
\hline & & \multirow{9}{*}{ Built-up areas } & Residential buildings \\
\hline & & & Service and trade buildings \\
\hline & & & Office buildings \\
\hline & & & Public service buildings \\
\hline & & & Sacral buildings \\
\hline & & & Industrial and storage buildings \\
\hline & & & Transport buildings \\
\hline & & & Outbuildings \\
\hline & & & Technical infrastructure buildings \\
\hline
\end{tabular}

*Areas with a dominant share of greenery and biologically active areas and a faint share of buildings.

**Areas that are strictly under buildings and the land surrounding them, serving the function of a building (i.e., lawn and squares) as well as transport areas. 

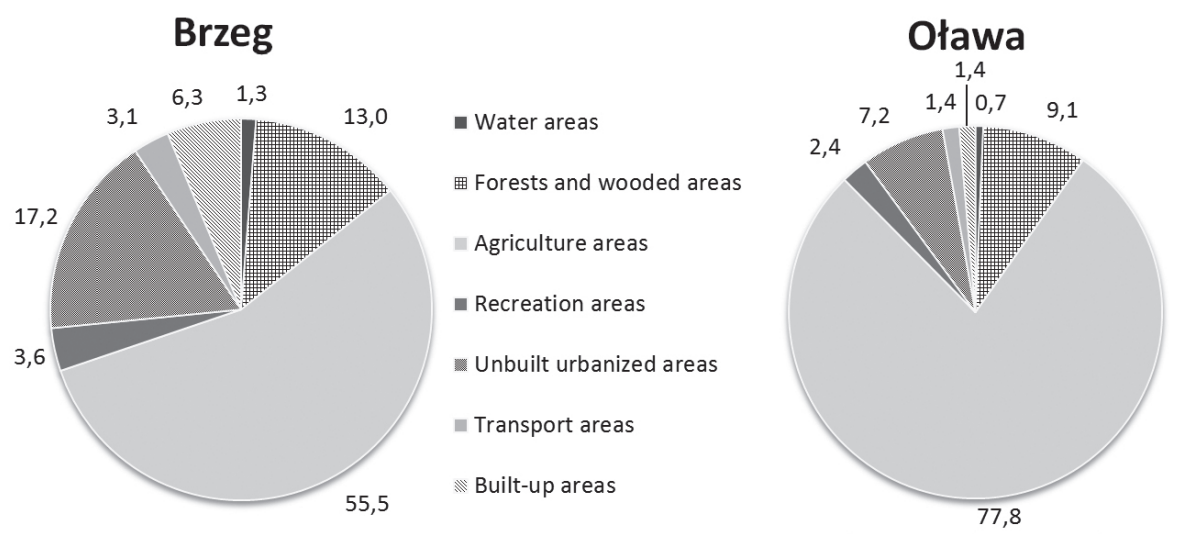

Fig. 3. Structure of floodplains land use in Oława and Brzeg in 2010.

higher percentage of "sealed" areas (on average 19.8\%) and a lower percentage of forest and agricultural land as well as water areas (on average $65.4 \%$ ) in comparison to the regions at direct risk of flooding $(8.7 \%$ and $83.8 \%$, respectively).

In the structure of the development of analysed floodplains, both embanked and unembanked, agricultural use predominates (Fig. 3), which has been observed also by Rast, Obrdlik, and Nieznański [27]. The presence of extremely fertile soils - river alluvial soils and, in drained areas cut off from the river by embankments in Oława, gley soils - is favourable to that.

Unembanked areas in Brzeg are less frequently used in agriculture and are more forested than embanked areas in Oława (Fig. 3). It can stem from diverse water and soil conditions caused by the embankment in the embanked areas. The creation of an embankment in natural floodplains upsets the water and soil relationship in the river valley. In the areas cut off from the river by embankments the level of groundwater lowers and, as a result, in the embanked valley in Oława, arable areas predominate in the structure of the usage of agriculture areas $(71.5 \%)$, while in unembanked areas in Brzeg meadows, pastures, and wooded and bushy land prevail $(65.3 \%)$.

The presence of the embankment is not without influence on the size of small water retention, which consists in the surface accumulation of water (in natural and artificial bodies of water). It is greater in the unembanked areas in Brzeg than in the embanked areas in Oława (Fig. 3).

Generally, the analysed floodplains are quite forested for urban areas (within the administrative borders of the cities), while the unembanked floodplains in Brzeg are more forested and wooded than the embanked floodplains in Olawa (Fig. 3). In both cities the forested, wooded, and bushy land can be found mainly in the first flood zone (Table 3). On the one hand, it is a favourable situation due to the areas that are wooded and abundant in bushy vegetation increasing the retention capabilities of the valley through limiting the surface flow of waters, simultaneously increasing the capabilities of retaining them in the soil [cf. 14, 24]. However, on the other hand, the trees grow- ing in the inter-embankment zone increase the roughness of floodplains and limit the flow capacity of the inter-embankment zone, which can lead to the banking up of the flood wave and the increase in its destructive power [cf. 14, 32-34].

The embanked areas in Oława are less used for recreational purposes than the unembanked areas in Brzeg (Fig. 3). It could be concluded that the separation of the city from the river with embankments is not favourable to the recreational use of river valleys. The rarity of using analysed riversides for recreational purposes is, on the one hand, positive in the environmental aspect, due to precious riverside vegetation and animal habitats not being endangered by negative effects of recreational activities. However, on the other hand, a lot of recreational potential of river valleys remains unused.

The unembanked floodplains in Brzeg are more invested than the embanked floodplains in Olawa (Fig. 3). In the unembanked floodplains the majority of buildings is located in the first flood zone, while in the embanked floodplains lies the second flood zone (Table 3). It mainly arises from the law of determinants of spatial economy in Polish floodplains. As the maps of floodplains used in the study are not binding in a legal and planning capacity, in the analysed area the prohibition and restriction of development applies only to the inter-embankment zones, therefore it applies solely to embanked areas. To prohibit development on unembanked areas, the study of flood protection identifying the range of direct hazard of flooding should be drawn up in relation to the analysed year of 2010. Therefore, the location of embankments within the city limits causes, to a degree, the distancing between the buildings and the river, helping to preserve and protect precious riverside biotopes, usually located in the immediate neighbourhood of the river.

In the analysed unembanked areas, due to the legal right of building closer to rivers, the share of industrial and warehouse buildings as well as technical infrastructure in the surface of floodplains is bigger in Brzeg than in the embanked floodplains in Oława (Fig. 3). The location of industrial buildings and technical infrastructure (including a sewage treatment plant) by the riverside may stem from 
Table 3. Structure of floodplain land use in individual flood zones in Oława and Brzeg in 2010 (\%).

\begin{tabular}{|c|c|c|c|c|}
\hline \multirow{2}{*}{$\begin{array}{c}\text { Land use } \\
\text { (second and third levels) }\end{array}$} & $\begin{array}{c}|c| \\
\text { Areas at direct risk } \\
\text { of flooding }\end{array}$ & $\begin{array}{c}\text { Areas at potential risk } \\
\text { of flooding }\end{array}$ & $\begin{array}{c}\text { Areas at direct risk } \\
\text { of flooding }\end{array}$ & $\begin{array}{c}\text { Areas at potential risk } \\
\text { of flooding }\end{array}$ \\
\hline Water areas & 0.1 & 0.8 & 1.4 & 0.0 \\
\hline Forests and wooded areas & 19.3 & 7.4 & 13.6 & 9.1 \\
\hline Agriculture areas & 74.9 & 78.3 & 58.2 & 35.2 \\
\hline Recreation areas & 0.3 & 2.7 & 3.2 & 7.3 \\
\hline $\begin{array}{c}\text { Unbuilt urbanized areas, } \\
\text { including: }\end{array}$ & 4.7 & 7.7 & 15.2 & 32.1 \\
- lawn & 4.0 & 5.3 & 7.8 & 14.3 \\
\hline - squares & 0.7 & 2.4 & 2.7 & 17.8 \\
\hline Transport areas & 0.4 & 1.6 & 5.7 & 5.6 \\
\hline Built-up areas & 0.3 & 1.5 & 115.2 & 10.7 \\
\hline
\end{tabular}

the production plant's high demand for water during the technological process and the facilitated pouring of purified sewage to the river. Industrial and technical buildings, especially the ones at direct hazard of flooding, constitute potential emitters of pollution in case of a flood; they are a threat for both the natural environment and man. However, in the embanked floodplains in Oława, the majority of such buildings, including the sewage treatment plant, is located in the second flood zone and is protected by the embankments (Table 3 ). On a positive note, there are no other potential sources of environmental pollution (e.g., cemeteries) that especially dangerous at times of flooding in the analyzed areas (both embanked and unembanked).

The issues discussed in this study are particularly crucial in terms of the development of areas protected by law and having high natural value. In Oława, within the land of Natura 2000 at hazard of flooding, agricultural areas predominate $(85.1 \%)$. Only $2.8 \%$ of the analysed Natura 2000 land is invested as a dispersed homestead development with the attached lawn, squares, and roads $(3.9 \%$ semi-invested areas, $8.2 \%$ water and forests and wooded areas; Fig. 1). In contrast, in Brzeg, $60.4 \%$ of the Natura 2000 land is agricultural, while $23.9 \%$ is invested (the built-up areas, lawn, squares, and roads; $6.3 \%$ semi-invested areas, 9.4\% water and forests and wooded areas). Areas of industrial development together with a sewage treatment plant situated in the Odra Islands are located within the Natura 2000 areas.

The land use patterns for the Odra in the inter-embankment zone correspond to the other research results. The studies on urban land use development patterns of the Potok Służewiecki catchment area in Warsaw (Poland) showed a predominant share of arable land areas. Also, a significant share of service and residential areas could be noticed there [35]. Analogue outcomes could be found in other cities in Poland [36], as well as in India [15] and France [18]. In addition, as Więzik [37] stresses, becau- se of the embankment construction arable lands are often turned into grasslands (meadows and pastures), and the dikes protect mainly build-up areas (residential, service, and industrial area) and main transport facilities. Also, as Habersack, Shober, and Hauer [9] note, the existence of embankments contributes to the creation of new development areas since part of the floodplain is detached from the river.

According to this research, while the meadows and pastures prevailed in the inter-embankment zone, a significant share of built-up areas has been noticed in the floodplain area protected by the dikes. As Plit [38] notes, the increase of built-up areas and the development of new housing estates in the floodplains just behind the embankments is very common in Poland and can be observed in many Polish cities that are also located along the Odra.

\section{Conlusions}

Despite embankment construcion undoubtedly interfering with the environment, analysis shows that the structure of floodplain development in the case of Oława river embankments is more beneficial from the perspective of the functioning of the natural environment and the environmental protection of riversides than in the unembanked river in Brzeg. In an analysed case it is caused by the total absence of formal regulation in the range of spatial planning of unembanked areas. This stems from the following observations:

- In the embanked river valley in Oława the floodplains are less altered by people and are therefore more natural than the unembanked floodplains in Brzeg. The percentage of forest and wooded and bushy land as well as agricultural land or land with surface waters in the general surface of floodplains is higher in Oława than in Brzeg. 
- The embanked river valley in Oława has less limited retention capabilities than the unembanked one in Brzeg, as it is less "sealed" due to the lower proportion of slightly permeable and impermeable areas (builtup areas, roads, and squares).

- The embanked river valley in Oława has no potential emitters of environmental pollution in the range of flood hazard zones, which in Brzeg are located in the unembanked areas.

- The manner of development of Natura 2000 areas, from the perspective of the protection of riverside value, is more favourable in Oława than in Brzeg. The riverside Natura 2000 areas in Oława are more similar to the natural ones, with the combined percentage of agricultural and forested land as well as those covered with water higher than in Brzeg, while of invested land it is lower.

In both analysed areas the regions at direct risk of flooding are less altered by people (they are more "natural" and less "sealed") than the regions at potential risk of flooding. However, it should be mentioned that in the case of the embanked areas the difference in the degree of investment (influencing the degree of alteration of the natural environment by humans) of both floodplain areas is greater than in the unembanked areas.

With regard to the environment in urban areas, embankments protect and conserve floodplain ecosystems as they limit urban development in the inter-embankment zone. On the other hand, they lead to the change of water and soil conditions in the river valley. Concerning spatial planning policy, in turn, dikes allow for the development of built-up areas in the river valley, and in consequence the increase of potential flood losses. On the other hand, they protect some facilities that constitute potential emitters of pollution in case of flooding.

On the basis of the conducted analysis on the manner of development of floodplains in Brzeg and Oława, an embankment is a crucial anthropogenic element differentiating the manner of the development of land in river valleys. It is largely determined through hydrology (the change of water and soil conditions due to the creation of an embankment), but also by legal regulations in the range of spatial planning and the economy in a floodplain area.

The older levees in Oława are based on dated building regulations. Also, at that time the floodplain areas were much less developed, and in consequence the maximum flow of the Odra was lower.

Hence, most segments of the embankments should now be reclassified. As a result, the levees should be heightened and reconstructed: their spacing and interembankment zones need be extended. However, there are many cases where the river valleys are highly urbanized and there is no possibility of removing or moving existing embankments [37].

The manner in which floodplains are developed currently is a result of centuries of expansion manifested in the development of built-up areas and adaptation of land for agricultural purposes. As a general rule, cities were located in the river valleys in their higher river banks, main- ly due to the proximity to water and defence purposes. The urbanized floodplains could only either retreat or diminish flood losses by the development of flood control methods [39].

With the subsequent urbanization of floodplains, more and more people have been exposed to flooding. Today, increasing urbanization has made it impossible to completely withdraw human activities from flood risk areas, especially in cities where there is no possibility to transfer threatened settlements to the safer locations [28]. Such transfers are too politically tough and socially disruptive (Liao 2014, pp. 723-724), thus "existing built-up areas can only count on flood control infrastructure" that "stabilizes the floodplain to allow urbanization and economic growth" [39, pp. 723-724].

The levees create a false sense of security that lowers vigilance to flood risk and encourages people to place new developments and investments just behind the embankments in the floodplain area, which was shown in this and other research [12, 28, 40-42].

Due to social pressures, the expenditures for flood protection of cities increases what leads to further floodplain urbanization $[8,15]$. Current conditions in floodplain areas are therefore the result of the urban design choices made in response to the demand for space without flood risk assessment [cf. 26].

Because floodplains are attractive both for agricultural production and housing, service and idustrial locations, there is high pressure by investors on their spatial development. On the other hand, floodplains also play a key role for flood protection, are a refuge for many bird species and water plants, are attractive from the landscaping point of view, and are appealing for recreational pursuits [9]. In order to reconcile the needs of social and economic development of cities, flood protection and nature conservancy, sustainable development principles for urban floodplain areas need to be applied $[2,5,8$, $12,19,43]$.

In accordance with these principles, we should seek some solutions that both reduce the flood risk understood as city or town economic development barriers and take into account the economic benefits of flood protection and nature conservancy [43]. According to Schober, Hauer, and Habersack [14], sustainable land use planning should also bring back the interaction between floodplains and river channels.

What's crucial for flood prevention, especially in urban areas, is a spatial planning policy. Many researchers consider land use planning as the most effective form of flood protection that reduces flood risk, especially in dense urban areas [5, 8, 17, 19, 45].

The basic principles of spatial management policy in the floodplains should tend toward the reduction of the builtup areas, decreasing the number the new investments, and controling the use of these lands. In other words, spatial planning is aimed at controlling urbanization processess in such areas in order to protect people and their properties from flooding [19]. In order to realize this goal, a strategy for urban area development needs to be formed that 
decides whether to invest within the city bearing in mind that it increases flood risk for people and raises the costs of flood protection, or to develop new built-up areas outside the city, with very low or no flood risk but usually with greater distances to the city center.

\section{Acknowledgements}

This work was funded by the National Science Center based on decision No. DEC-2011/03/N/HS4/00436.

\section{References}

1. BURGESS O.T., PINE W.E., WALSH S.J. Importance of floodplain connectivity to fish populations in the Apalachicola River, Florida. River Research and Applications, 29, 6, 2013.

2. CZOCH K., KULESZA K., WALCZYKIEWICZ W. Restoration and revitalization of rivers and streams as a part of the sustainable development of river valleys. In: The legal, administrative and environmental determinants of river valleys development. Ed. Higher School of Administration. Bielsko-Biała, 2010 [In Polish].

3. ADAMSKI A. The natural habitats of european importance related to river valleys in Poland. How to effectively protect nature of river valleys? The training materials for the participants of a workshop organized by the Society for Earth and Polish Green Network, available at: www.tnz. most.org.pl/dokumenty/projekty/jak chronic 2007 58sth. pdf (last access: April 2015), 2007 [In Polish].

4. REUBEN B., POESEN J., DANJON F., GEUDENS G., MUYS B. The role of fine and coarse roots in shallow slope stability and soil erosion control with a focus on root system architecture: A review. Trees, 21, 2007.

5. RICHERT E., BIANCHIN S., HEILMEIER H., MERTA M., SEIDLER C. A method for linking results from an evaluation of land use scenarios from the viewpoint of flood prevention and nature conservation. Landscape and Urban Planning, $103,2,2011$

6. KUNDZEWICZ Z.W., MENZEL L., Natural flood reduction strategies - a challenge. International Journal of River Basin Management, 3, 2, 2005.

7. OPPERMAN J.K., GALLOWAY G.E., FARGIONE J., MOUNT J.F., RICHTER B.D., SECCHI S., Sustainable floodplains through large-scale reconnection to rivers. Science 326, 2009.

8. GROCKI R., ELIASIEWICZ R., The floodplains development. Project Coordination Office of the World Bank. Series: Reducing of Effects Flood in the Local Scale. Ed. Safaga, Wrocław, 2001.

9. HABERSACK H., BERNHARD SCHOBER B., HAUER C., Floodplain evaluation matrix (FEM): An interdisciplinary method for evaluating river floodplains in the context of integrated flood risk management. Natural Hazards, 75, 2015.

10. ALI S., GHANI U., ARIF S., Estimation of Flow Resistance Due to Embankments and Spur Dikes during Floods. Mehran University Research Journal of Engineering and Technology, 32, 3, 2013

11. SHOLTES J.S., DOYLE M.W., Effect of channel restoration on flood wave attenuation. Journal of Hydraulic Engineering, $137,2,2011$
12. $\operatorname{COM}(2004) 472$ final, Opinion of the European Economic and Social Committee on the Communication from the Commission to the Council, the European Parliament, the European Economic and Social Committee and the Committee of the Regions - Flood risk management - Flood prevention, protection and mitigation $(\mathrm{COM}(2004) 472$ final). Official Journal of the European Union, 8.9.2005, C 221/08, 2005

13. DE KOK J.L., GROSSMANN M. Large-scale assessment of flood risk and the effects of mitigation measures along the Elbe River. Natural Hazards, 52, 2010.

14. RAK G., KOZELJ D., STEINMAN F. The impact of floodplain land use on flood wave propagation. Natural Hazards, 83, 2016.

15. SURIYA S., MUDGAL B.V. Impact of urbanization on flooding: The Thirusoolam sub watershed - a case study. Journal of Hydrology, 412, 2012.

16. BRONSTERT A., BARDOSSY A., BISMUTH C. BUITEVELD H., DISSE M., ENGEL H., FRITSCH U., HUNDECHA Y., LAMMERSEN R., NIEHOFF D., RITTER N. Multi-scale modelling of land-use change and river training effects on floods in the Rhine basin. River Research and Applications, 23, 10, 2007.

17. WHEATER H., EVANS E. Land use, water management and future flood risk. Land Use Policy, 26, 2009.

18. FOX D.M., WITZ W., BLANC V., SOULIÉ C., PENALVERNAVARRO M., DERVIEUX A. A case study of land cover change (1950-2003) and runoff in a Mediterranean catchment. Applied Geography, 32, 2, 2012.

19. RISTIĆ R., KOSTADINOV S., ABOLMASOV B., DRAGIĆEVIĆ S., TRIVAN G. RADIĆ B., TRIFUNOVIĆ M., RADOSAVLJEVIĆ Z. Torrential floods and town and country planning in Serbia. Natural Hazards Earth System Sciences, 12, 1, 2012.

20. DU S., VAN ROMPAEY A., SHI P., WANG J. A dual effect of urban expansion on flood risk in the Pearl River Delta (China) revealed by land-use scenarios and direct runoff simulation. Natural Hazards, 77, 2015.

21. ZOPE P.E., ELDHO T.I., JOTHIPRAKASH V. Impacts of urbanization on flooding of a coastal urban catchment: a case study of Mumbai City, India. Natural Hazards,75, 2015.

22. LI J.,TAN S., CHEN F., FENG P. Quantitatively analyze the impact of land use/land cover change on annual runoff decrease. Natural Hazards, 74, 2014.

23. REMO J.W.F., CARLSON M., PINTER N. Hydraulic and flood-loss modeling of levee, floodplain, and river management strategies, Middle Mississippi River, USA. Natural Hazards, 61, 2012.

24. CA WALUP How Urbanization Affects the Water Cycle, The California Water and Land Use Partnership, available at: http://www.coastal.ca.gov/nps/watercyclefacts.pdf (last access: March 2013), 2009.

25. CIUPA T. The impact of land use on runoff and fluvial transport in small catchments on the exapmle of Sufragańca and Silnica. Kielce, 2009 [In Polish].

26. LUINO F., TURCONI L., PETREA C., NIGRELLI G. Uncorrected land-use planning highlighted by flooding: the Alba case study (Piedmont, Italy). Natural Hazards Earth System Sciences, 12, 7, 2012.

27. RAST G., OBRDLIK P., NIEZNAŃSKI P. The Atlas of the Odra Floodplain Areas. Ettlingen, 2000 [In Polish].

28. JERMACZEK A., MISZTAL K., WASIAK P. The causes and effects of the floods in Lower Silesia - proposals for environmental flood activity. Gorzów Wielkopolski, 2008 [In Polish]. 
29. GŁOSIŃSKA G., SOBCZYŃSKI T., BOSZKE L, BIERŁA K., SIEPAK J. Fractionation of Some Heavy Metals in Bottom Sediments from the Middle Odra River (Germany/Poland). Polish Journal of Environmental Studies, 14, 3, 2005.

30. BÖHM H., R., ZALESKI J. DENDEDOWIZ J., DENDEDOWICZ S., FRIEDRICH S., GRETZCHEL O., NEUMULLER J., REENTS M., TIUKAŁO A. The preventive flood protection in the Odra - transnational action program in the terms of spatial planning and water management. The final report OderRegio INTERREG IIIB Cades. Mutual Spatial Planning Department of the Länder Berlin and Brandenburg, Potsdam, 2006 [In Polish].

31. CIOŁKOSZ A., POŁAWSKI Z. F. A changes in land use in Poland in the second half of the twentieth century. Przegląd Geograficzny 78-2, Warszawa, 2006 [In Polish].

32. FORZIERI G., GEGETTO M. RIGHETTI M., CASTELLI F., PRETI F. Satellite multispectral data for improved floodplain roughness modelling.Journal of Hydrology, 407, 1-4, 2011.

33. STRAATSMA M. 3D float tracking: in situ floodplain roughness estimation. Hydrological Processes, 23, 2, 2009.

34. KISS T., SÁNDOR A., Land-use changes and their effect on floodplain aggradation along the Middle-Tisza river, Hungary. AGD Landscape and Environment, 3, 1, 2009.

35. OKSIUTA M., Transformations hydrographic network and land use in the urban area (catchment Potok Służewiecki, Warsaw). Prace Geograficzne, 120, 2008[In Polish].

36. DUDA R., GRĘPLOWSKA Z., JARZĄBEK A., MAZOŃ S., NACHLIK E., SZCZEPAŃSKA S., SZCZEPAŃSKI A., WITCZAK S. The characteristics of Raba catchment. In: Nachlik E. (Ed.), Identification and assessment of anthropogenic impacts on the water resources of the Raba catchment with the estimation of risk of achievement failure of the environmental objectives. Ed. Cracow University of
Technology, serie Inżynieria Środowiska, Monografia, 340, 2006 [In Polish].

37. WIĘZIK B., The impact of inter-embankment zone on flood hazard. In: Więzik K. (Ed.), The legal, administrative and environmental determinants of river valleys development. Ed. Higher School of Administration, Bielsko-Biała, 2010 [In Polish].

38. PLIT J. A landscape management of river valleys. Prace Komisji Krajobrazu Kulturowego, 10. PTG, Sosnowiec, 2008 [In Polish].

39. LIAO K-H. From flood control to flood adaptation: a case study on the Lower Green River Valley and the City of Kent in King County, Washington. Natural Hazards, 71, 2014.

40. ASFPM (The Association of State Floodplain Managers). Best practices on flood prevention, protection and mitigation. Copenhagen, 2002.

41. DI BALDASSARRE G., CASTELLARIN A., BRATH A. Analysis on the effects of levee heightening on flood propagation: some thoughts on the River Po. Hydrological Sciences Journal, 54, 6, 2009.

42. LANE S.N., LANDSTROM C., WHATMORE S.J., Imagining flood futures: risk assessment and management in practice. Philosophical Transactions of the Royal Society A, 369, 2011.

43. NACHLIK E. Place of flood protection in programming socio-economic development. Gospodarka Wodna, 7, 2007[In Polish].

44. SCHOBER B., HAUER C., HABERSACK H. A novel assessment of the role of Danube floodplains in flood hazard reduction (FEM method). Natural Hazards, 75, 2015.

45. KAŹMIERCZAK A., CAVAN G. Surface water flooding risk to urban communities: Analysis of vulnerability, hazard and exposure. Landscape and Urban Planning, 103, 2011. 
